\title{
SUBSTITUTION OF CORNMEAL FOR FLOUR OF SHOOTS AND NON- \\ COMMERCIAL ROOTS OF ARRACACHA (ARRACARIA XANTHORRHIZA \\ BANCROFT) IN THE PROCESSING OF SEMISWEET BISCUITS
}

\author{
ROSIMEIRE PEREIRA GASSI ${ }^{*}$ \\ NÉSTOR ANTONIO HEREDIA-ZÁRATE** \\ ELIANA JANET SANJINEZ-ARGANDOÑA*** \\ ELISSANDRA PACITO TORALES**** \\ MARIA DO CARMO VIEIRA***** \\ LUAN RAMOS DA SILVA******
}

\begin{abstract}
The objective was to develop cornmeal semisweet biscuits with the addition of flour of shoots and non-commercial roots of arracacha (Arracacia xanthorrhiza Bancroft) and evaluate their nutritional implications and physical characteristics of the product. The flours were obtained from fresh samples of shoots and non-commercial roots of arracacha. Biscuits were prepared in different concentrations of cornmeal, flour of shoots and non-commercial roots of arracacha, totaling seven trials. The flours and the biscuits were nutritionally analyzed and the cost of production was determined. That substitution of cornmeal by flour of non-commercial roots up to 50 $\%$ provided lower-calorie biscuits with higher fiber content. Flour of shoots favored the increase of fibers; however, the biscuits had a darker color and harder texture. In conclusion, the addition of arracacha residues in the production of biscuits promoted increased fiber content and reduced the calorie value.
\end{abstract}

KEY-WORDS: PERUVIAN CARROT; TUBEROUS WASTE; FLOUR; FIBERS.

*Doutora em Agronomia, Universidade Federal da Grande Dourados (UFGD) Dourados, MS (e-mail: rpgassi@ yahoo.com.br)

**Doutor em Fitotecnia, Professor Titular, Universidade Federal da Grande Dourados (UFGD) Dourados, MS (e-mail: nestorzarate@ufgd.edu.br)

***Doutora em Engenharia de Alimentos, Professora, Universidade Federal da Grande Dourados (UFGD) Dourados, MS (e-mail: elianaargandona@ufgd.edu.br)

****Doutora em Agronomia, Pós doutoranda, Universidade Federal da Grande Dourados (UFGD) Dourados, MS (e-mail: ninapacito@hotmail.com)

*****Doutora em Fitotecnia, Professora Titular, Universidade Federal da Grande Dourados (UFGD) Dourados, MS (e-mail: mariavieira@ufgd.edu.br)

******Graduando em Engenharia de Alimentos, Universidade Federal da Grande Dourados (UFGD) Dourados, MS (e-mail: luanramoos@yahoo.com.br) 


\section{INTRODUCTION}

The eating habits of some consumers today requires immediate interference of food technology in order to sustain and/or increase the life expectances of humans. This is an issue today because people often choose food that they enjoy but that otherwise does not offer proper nutrition. Chronic diseases generally result from deficient diets in protein, vitamins or other nutritional components. The availability of an abundant food supply does not necessarily guarantee the people survival, unless the food is nutritionally complete and does not contain harmful substances (HEREDIA-ZÁRATE and VIEIRA, 2004).

In the wide range of nutritious foods, there are unconventional foods like arracacha (Arracacia xanthorrhiza Bancroft), also known as Peruvian carrot, taro [Colocasia esculenta (L.) Schott] and others with important nutritional characteristics. Data on non-conventional foods are scarce and may have an important role in balanced diets; and may assist in supplementing calcium, iron, vitamin C, protein, fiber, carbohydrates and other nutritional components, where it is well known that much of the population is lacking (PINTO et al., 2000).

The arracacha originated in the Andes and was introduced in Brazil at the beginning of the XX century (ZANIN and CASALI, 1984). It features names like batata-aipo, batata-baroa, batata-fiúza or barão. For its content of minerals, fibers and B vitamins, it is important in the diet of children, elders and convalescents, being also much appreciated for its characteristic taste and aroma (CÂMARA AND SANTOS, 2002). It is usually consumed in the form of soup, boiled and used to make bread and cakes. The United Nations for Food and Agriculture Organization (FAO) recognizes that arracacha is a species of high nutritional, economic, productive value with the potential to be used in industries and even as medicine (AÑES, ESPINOZA \& VÁSQUEZ, 2002).

In Mato Grosso do Sul, the arracacha 'Amarela de Carandai' has a vegetative cycle of seven to eight months, with yields ranging from 10 to $15 \mathrm{tha}^{-1}$ commercial root and between 25 and $35 \mathrm{t} \mathrm{ha}^{-1}$ waste (leaves, crown, shoots and non-commercial root) (GRACIANO et al., 2007). VIEIRA and HEREDIA-ZÁRATE (2002) reported that the commercial roots represent 20-30\% of the fresh matter of the plant, while leaves, shoots, crowns and non-commercial roots make up the remaining 70 to $80 \%$, which are considered disposable waste, although the dry matter of these non-tradable parts have $8.44 \%$ of fixed mineral residue; $0.80 \%$ of ether extract; $10.52 \%$ of protein; $53.90 \%$ of starch; $15.45 \%$ of fiber and $264.92 \mathrm{kcal} 100 \mathrm{~g}^{-1}$ of total caloric value. PEREIRA et al. (2003) reported that these residues are generally disposed, but could be utilized as alternative sources of fiber and minerals, among others.

Several studies have reported the use of waste generated during the plant processing to obtain products with higher added value such as biscuits prepared from potato waste (PEREIRA et al., 2005) or wheat and rice bran (FEDDERN et al., 2011). The biscuits are among the most popular products consumed by people of all ages and social classes. This is mainly due to events such as ease of use, good nutritional quality, availability in different varieties and low cost. Such a product with these characteristics proves to be a good vehicle for the study of mixed flours, whether for economic or nutritional reasons (ASSIS et al., 2009).

The application of mixed flours technology can be used in bakery products since the partial substitution will not cause injury to the final quality of the finished products (EL-DASH and GERMANI, 1994; PAPANTONIOU et al., 2003). The use of flour of shoots and and non-commercial root of the arracacha in production of biscuits can add economic and nutritional value to that resource.

Given that few studies related to the use of some non-commercial waste of arracacha plant, especially the disposable amidic parts, the goal is to work in developing cornmeal semisweet biscuits with the addition of flour of shoots and non-commercials roots of arracacha and evaluating their nutritional implications and consequential influence on the physical characteristics of the product. 


\section{MATERIAL AND METHODS}

The work was developed in the Laboratory of Agricultural Products Technology, Faculty of Agricultural Sciences-FCA and the Laboratory of Food Technology, Faculty of Engineering-FAEN at the Federal University of Grande Dourados - UFGD, in Dourados, MS, Brazil.

\subsection{RAW MATERIAL}

The arracacha "Amarela de Carandai" was collected from an experiment conducted in the Horto de Plantas Medicinais (HPM), FCA. Fresh samples of shoots (morphological component of the plant used as seedling) and non-commercial roots (roots with physical damage and / or mass less than 25.0 grams) were fractionated separately into pieces and dried for 72 hours at $60 \pm 5^{\circ} \mathrm{C}$ in an oven with circulating air $\left(1.0 \mathrm{~ms}^{-1}\right.$ speed). The dried product was ground in a circular rotor macro mill with fixed and mobile knives, "CROTON" type (Marconi - MA-580), and sieved through mesh with holes of $1 \mathrm{~mm}$ diameter, to obtain a flour with homogeneous particle size. Flours of shoots and non-commercial roots were placed separately on flexible polyethylene bags and stored at $25{ }^{\circ} \mathrm{C}$, protected from light until use.

The yield of flours was calculated by the ratio of fresh weight of shoots and non-commercial roots of arracacha plants and the masses of flours obtained were expressed in percentage.

\subsection{BASIC FORMULATION AND MANUFACTURING PROCESS OF BISCUITS}

The semisweet biscuit manufacturing used several ingredients: cornmeal and flours of shoots and non-commercial roots of arracacha, sugar, butter, eggs, cassava starch and water. The biscuits were semisweet, not fermented and round in shape.

The standard formulation of semisweet biscuit is shown in Table 1. Biscuits made with substitution of cornmeal (CM) were prepared using flour of shoots (FS) or non-commercial roots (FNCR) of arracacha. The process of preparing biscuits originally consisted of hand mixing the butter with sugar and eggs until smooth. Subsequently, CM, FS or FNCR, cassava starch and water were added. Next, the dough was divided into portions $(13 \mathrm{~g})$ and molded manually. The biscuits were baked in a domestic oven at $180{ }^{\circ} \mathrm{C}$ for 35 minutes. After baking, the biscuits were cooled to room temperature and immediately packaged in polyethylene bags. The vials were sealed, stored in glass containers and stored from light at $25^{\circ} \mathrm{C}$ until further analyses.

TABLE 1 - STANDARD FORMULATION OF SEMISWEET BISCUIT

\begin{tabular}{cc}
\hline Ingredients & Quantity (\%) \\
\hline Cornmeal & 27.60 \\
\hline Sugar & 13.60 \\
\hline Butter & 13.60 \\
\hline Eggs & 9.00 \\
\hline Cassava starch & 30.10 \\
\hline Water & 6.10 \\
\hline
\end{tabular}




\subsection{EXPERIMENTAL DESIGN}

To study the effect of cornmeal substitution for flours of shoots and non-commercial roots on biscuits formulation, a simplex centroid experimental design was performed (Table 2), with seven trials. To observe effects of variables and their interactions on the responses evaluated (fiber, color and texture), a response surface plot was performed.

TABLE 2 - CENTROID SIMPLEX EXPERIMENTAL DESIGN FOR FORMULATING SEMISWEET BISCUITS WITH CORNMEAL AND FLOURS OF SHOOTS AND NONCOMMERCIAL ROOTS OF ARRACACHA 'AMARELA DE CARANDAI'' (ARRACACIA XANTHORRHIZA BANCROFT)

\begin{tabular}{cccc}
\hline \multirow{2}{*}{ Formulations } & \multicolumn{3}{c}{ Flour (\%) } \\
\cline { 2 - 4 } & Cornmeal & Shoot & Non-commercial root \\
\hline F1 & 0 & 100 & 0 \\
\hline F2 & 100 & 0 & 100 \\
\hline F3 & 0 & 0 & 0 \\
\hline F4 & 50 & 50 & 50 \\
\hline F5 & 0 & 50 & 50 \\
\hline F7 & 50 & 0 & 33 \\
\hline
\end{tabular}

\subsection{CHEMICAL AND PHYSICAL PROPERTIES OF BISCUITS}

The proximate composition of biscuits was determined by analyzing for moisture, fixed mineral residue, proteins, lipids and fiber (AOAC, 2000). Moisture was determined by gravimetric method, heating $105{ }^{\circ} \mathrm{C}$ to constant weight. The fixed mineral residue was obtained by sample calcination in muffle furnace at $550^{\circ} \mathrm{C}$. Protein content was determined by the Kjeldahl method. The Soxhlet method was used for lipids. The fiber content was determined by material digestion with a solution of $\mathrm{NaOH}(1.25 \%)$ and $\mathrm{H}_{2} \mathrm{SO}_{4}(1.25 \%)$. Carbohydrates were quantified by acid hydrolysis method (CARVALHO et al., 2006). All analyses were performed in triplicate.

The energy value of biscuits was calculated by multiplying the total percentages of lipids, proteins and carbohydrates in each sample, using the conversion factors of Atwater, namely: $9 \mathrm{kcal}$, $4 \mathrm{kcal}$ and $4 \mathrm{kcal}$, respectively (BRAZIL, 2006).

The texture of biscuits of each formulation was determined by measuring the shear strength (hardness) in texturometer TA - HDi (Stable Micro Systems, Godalming, UK) with TA 9/1000 rectangular steel blade HDP / LKB, operating under the following conditions: measure of strength at break, pre-test speed of $10.0 \mathrm{mM} . \mathrm{s}^{-1}, 3 \mathrm{~mm} \cdot \mathrm{s}^{-1}$ test and $10 \mathrm{~mm} \cdot \mathrm{s}^{-1}$ post-test, $30 \mathrm{~mm}$ distance, depth penetration of $20 \mathrm{~mm}$ between the support base and the blade and $0.1 \mathrm{~kg}$ strength. The biscuit was placed horizontally on a support platform and sliced in half by the blade. Measurements were determined in six biscuits of each formulation.

The color of the biscuits was assessed in twelve random units of each sample unit in the digital colorimeter (Konica Minolta, Model CR400) at $25^{\circ} \mathrm{C}$, adopting the CIELAB system. The values 
of $L$ * lightness or brightness (black 0 / white 100), a* (green - / red +) and b* (blue - / yellow +) were measured. The parameters evaluated were Chromaticity $\left(C^{*}\right)$ obtained by Eq (1), shade or Hue angle $\left(h^{*}\right)$ representing the colors red $\left(0^{\circ}\right)$, yellow $\left(90^{\circ}\right)$, green $\left(180^{\circ}\right)$ and blue $\left(270^{\circ}\right)$ calculated by Equation (2), and color variation ( $\Delta \mathrm{E})$, given by equation (3).

$$
\begin{aligned}
\mathrm{C}^{*}= & \sqrt{\mathrm{a}^{* 2}+\mathrm{b}^{* 2}} \\
\mathrm{~h}^{*} & =\arctan \frac{\mathrm{b}^{*}}{\mathrm{a}^{*}} \\
\ddot{\mathrm{E}} & =\sqrt{\mathrm{a}^{* 2}+\mathrm{b}^{* 2}+\mathrm{L}^{* 2}}
\end{aligned}
$$

\subsection{PRODUCTION COSTS}

The cost of biscuits was calculated from the quantities of ingredients needed to produce $100 \mathrm{~g}$ of baked product. The cost of ingredients was obtained at a wholesale market in July 2015.

\subsection{STATISTICAL ANALYSIS}

Results were expressed by the mean value of triplicates and submitted to analysis of variance, mean values compared by Tukey test $(p<0.05)$. Data processing was performed with Statistica version 8 software.

\section{RESULTS AND DISCUSSION}

\subsection{YIELD OF FLOURS}

Plants of arracacha, as reported by TORALES et al. (2014), have on average $15.51 \%$ of leaves, $11.73 \%$ of crown, $19.09 \%$ of shoots, $43.93 \%$ of commercial roots and $9.73 \%$ noncommercial roots. The shoots and non-commercial roots represent $28.82 \%$ of the plant. Thus, these by-products, usually discarded, have great potential for use as alternative ingredients for human or animal consumption. In the processing of drying and milling yield of flours of shoots was $19.12 \%$ and non-commercial roots was $22.22 \%$. These results are superior to those found by PEREIRA et al. (2005), who found $18 \%$ yield in potato waste flour. The high yield of flour of shoots (FS) and noncommercial roots (FNCR) of arracacha makes feasible the processing of baked goods like biscuits, cakes, breads, among others.

\subsection{PROXIMATE COMPOSITION}

The results of the proximate composition analyses of biscuits of different formulations were significantly different $(p<0.05)$, except for the fibers (Table 3 ). The biscuits of non-commercial parts of arracacha obtained moisture content between 7.13 and $12.96 \%$, with the exception of the formulation F1 (100\% replacement of cornmeal by flour of shoots), which showed $15.19 \%$, due to higher initial moisture content of the shoot. The other biscuit formulations had moisture within the specified by the Health Surveillance Agency (ANVISA), which determines $14 \%$ maximum moisture for the product (BRAZIL, 1978).

The fixed mineral residue content varied significantly $(p<0.05)$ between the standard formulation and elaborate formulations (Table 3). Biscuits with partial substitution of cornmeal by flours of shoots and non-commercial roots of arracacha showed less fixed mineral residue. However, the 
contents found in formulated biscuits are within the range established by the Brazilian legislation, which is at most $3.0 \%$ (BRAZIL, 1978). Regarding the protein content, the value obtained in cornmeal (4.10 $\%$ ) was $0.78 \%$, higher than that of flour of non-commercial roots of arracacha, which was the lowest one and less than $1.87 \%$ compared to flour of shoots of arracacha, which was the highest value.

The lipid content was higher in biscuits formulated with $100 \%$ and $50 \%$ flour of the shoots (formulations F1, F4 and F5), substituting cornmeal, which can be explained by lipid content (1.05 $\%$ ) that is found in this morphological component of arracacha (GRACIANO et al., 2007), influencing the total lipid content of the product.

Regarding the fiber content, there was no significant difference ( $p>0.05)$ among biscuits, but the highest contents were found in formulations with higher content of flour of shoots, F1 (2.53\%) and F4 (2.79 $\%$ ). The flour o shoots has about $25 \mathrm{~g} .100 \mathrm{~g}^{-1}$ fibers (GRACIANO et al., 2007). In the studied concentrations for the three variables cornmeal (CM), flour of shoots (FS) and flour of non-commercial roots (FNCR), it was found that in products formulated with $50 \% \mathrm{CM}$ and $50 \%$ FNCR there was increased fiber content (33 \%) and reduced caloric value ( $28 \%$ ) compared to the standard biscuit (F2). In biscuit made from $\mathrm{F} 7$ (33\% CM $+33 \% \mathrm{FNCR}+33 \% \mathrm{FS}$ ) the increased fibers was $44 \%$ and $25 \%$ calorie reduction.

\subsection{TEXTURE}

The parameters of texture and color of the biscuits are shown in Table 4. One can observe that the hardness values associated with the shear were higher in biscuits formulated with flour of shoots providing a harder product. The hardness of biscuits is proportional to the applied force to cause deformation. The maximum rated power is dependent on the formulation (flour quality, amount of sugars and fats), product moisture and storage conditions (ASSIS et al., 2009). Thus, the fiber content present in the shoots and non-commercial roots of arracacha (Table 3) seems to be responsible for the hardness, influencing the texture of the product, which corroborates the experimental data.

Biscuits made of flour of non-commercial roots showed up softer than biscuits made with flour of shoots in all formulations. However, there were no statistically significant differences between the samples due to device sensitivity and the consequent high standard deviation of the data obtained.

TABLE 4. TEXTURE PARAMETERS (HARDNESS) AND COLOR (LIGHTNESS, CHROMATICITY, TONALITY AND COLOR VARIATION) OF SEMISWEET BISCUITS MADE WITH CORNMEAL (CM), FLOURS OF SHOOTS (FS) AND NON-COMMERCIAL ROOTS (FNCR) OF ARRACACHA 'AMARELA DE CARANDAI'' (ARRACACIA XANTHORRHIZA BANCROFT)

\begin{tabular}{|c|c|c|c|c|c|c|}
\hline & Formulations & $\begin{array}{l}\text { Hardness } \\
\text { (N) }\end{array}$ & $\begin{array}{l}\text { Lightness } \\
\qquad\left(\mathrm{L}^{*}\right)\end{array}$ & $\begin{array}{c}\text { Cromaticity } \\
\left(C^{*}\right)\end{array}$ & $\begin{array}{c}\text { Tonality } \\
\left(\mathrm{h}^{*}\right)\end{array}$ & $\begin{array}{c}\text { Color variation } \\
\qquad(\Delta \mathrm{E})\end{array}$ \\
\hline F1 & $100 \%$ FR & 14546.70 & $\begin{array}{c}47.48 \pm \\
0.27 b\end{array}$ & $\begin{array}{c}22.63 \pm 0.01 \\
b\end{array}$ & $\begin{array}{l}1.17 \pm \\
0.00 \mathrm{~b}\end{array}$ & 35.22 \\
\hline $\mathrm{F} 2$ & $100 \% \mathrm{FM}$ & 7037.80 & $\begin{array}{c}77.65 \pm \\
0.18 \mathrm{c}\end{array}$ & $\begin{array}{c}37.00 \pm 0.09 \\
c\end{array}$ & $\begin{array}{l}1.56 \pm \\
0.00 \mathrm{c}\end{array}$ & 0.00 \\
\hline F3 & $100 \%$ FNCR & 10291.90 & $\begin{array}{c}70.65 \pm \\
0.13 a\end{array}$ & $\begin{array}{c}29.91 \pm 0.04 \\
a\end{array}$ & $\begin{array}{c}1.41 \pm 0.00 \\
\mathrm{~d}\end{array}$ & 11.13 \\
\hline F4 & $50 \%$ FM; $50 \%$ FR & 11157.50 & $\begin{array}{c}57.79 \pm \\
0.09 \mathrm{~d}\end{array}$ & $\begin{array}{c}23.86 \pm 0.20 \\
d\end{array}$ & $\begin{array}{l}1.34 \pm \\
0.00 \mathrm{a} \\
\end{array}$ & 24.69 \\
\hline F5 & 50 \% FR; 50 \% FNCR & 9144.90 & $\begin{array}{c}60.30 \pm \\
0.14 \mathrm{e}\end{array}$ & $\begin{array}{c}26.26 \pm 0.06 \\
\mathrm{e}\end{array}$ & $\begin{array}{l}1.34 \pm \\
0.00 \mathrm{a}\end{array}$ & 21.49 \\
\hline F6 & $50 \%$ FM; 50 \% FNCR & 8087.70 & $\begin{array}{c}74.85 \pm \\
0.03 f\end{array}$ & $\begin{array}{c}30.42 \pm 0.02 \\
a\end{array}$ & $\begin{array}{l}1.47 \pm \\
0.00 \mathrm{e} \\
\end{array}$ & 7.76 \\
\hline F7 & $\begin{array}{c}33 \% \text { FM; } 33 \% \text { FR; } \\
33 \% \text { FNCR }\end{array}$ & 9405.40 & $\begin{array}{c}69.23 \pm \\
0.02 \mathrm{a}\end{array}$ & $29.13 \pm 0.01 \mathrm{f}$ & $\begin{array}{l}1.36 \pm \\
0.00 f\end{array}$ & 13.81 \\
\hline
\end{tabular}




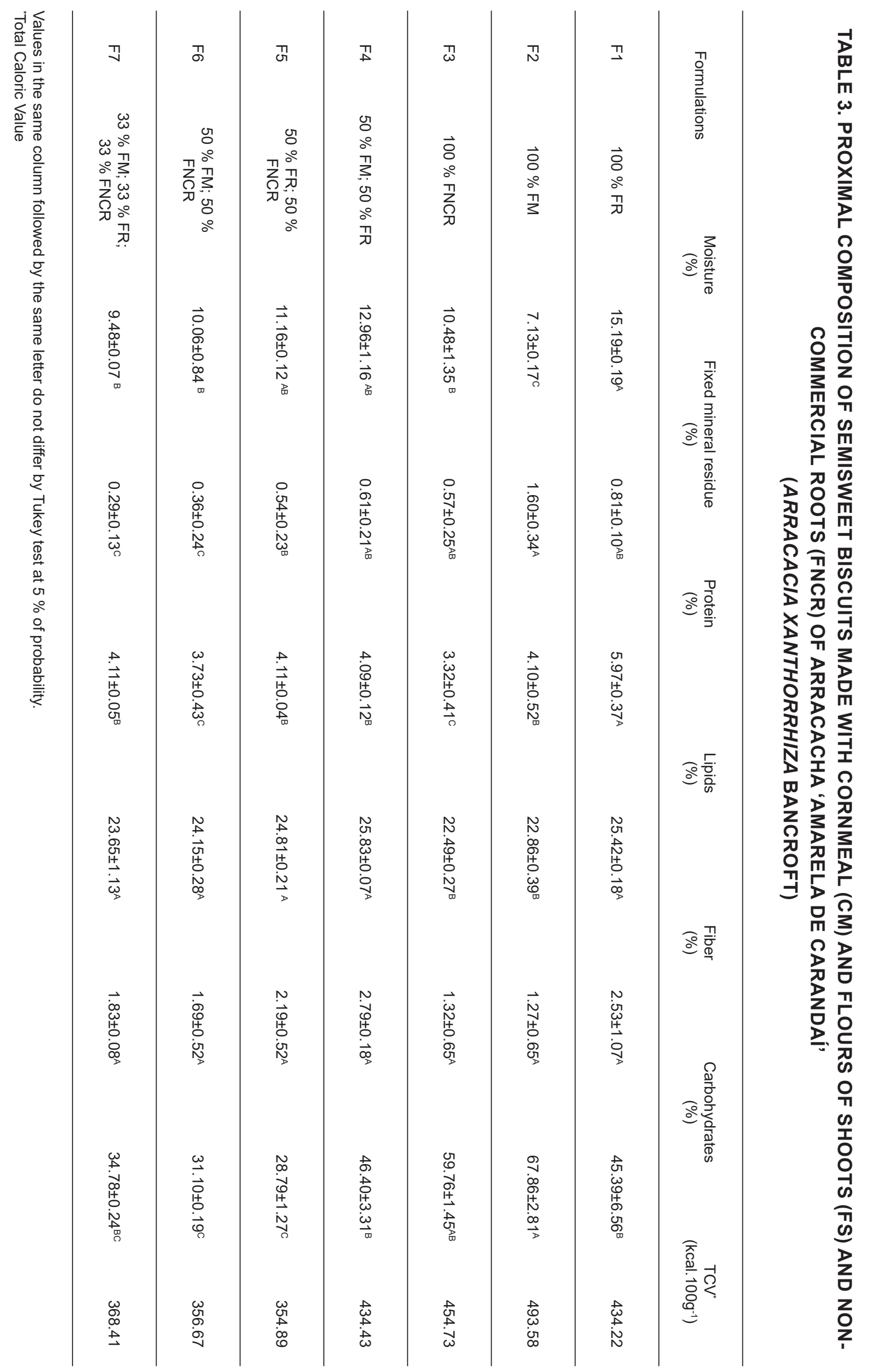




\subsection{COLOR}

Color parameters of biscuits formulated with cornmeal (standard formulation) and flours of shoots and non-commercial roots of arracacha are shown in Table 4. Adding the flours of arracacha significantly influenced $(p<0.05)$ the parameters of lightness $\left(L^{*}\right)$, chromaticity $\left(C^{*}\right)$ and shade $\left(h^{*}\right)$. The values of these parameters were reduced by replacing the $\mathrm{CM}$, providing a darker product, especially with the FS addition. In addition to these parameters, the color variation was also assessed for being one of the main parameters observed by the consumer influencing product acceptability.

In CM-based biscuits, the consumer expects to find the characteristic yellow corn color, before that, when replacing the $\mathrm{CM}$ by flours of shoots and non-commercial roots, changes in product color were observed. The significant effect of these flours on color variation $(\Delta \mathrm{E})$ is shown in Figure $1 \mathrm{~A}$. The biscuits made with flour of shoots had significantly $(p<0.05)$ darker color compared with the standard formulation (CM), which can be attributed to increased fiber content. The biscuits with added FNCR were also significantly different from the formulation with $\mathrm{CM}$, however the $\Delta \mathrm{E}$ was lower.

The response surface (Figure 1B) shows the effect of increasing substitution of CM by FS and / or FNCR of arracacha on increased color variation in biscuits. Flour of shoots has greater color variation than FNCR and CM, hence biscuits had darker color when the highest percentage of flour of shoots was added, which confirms the significant effect of flours of arracacha on the product color.

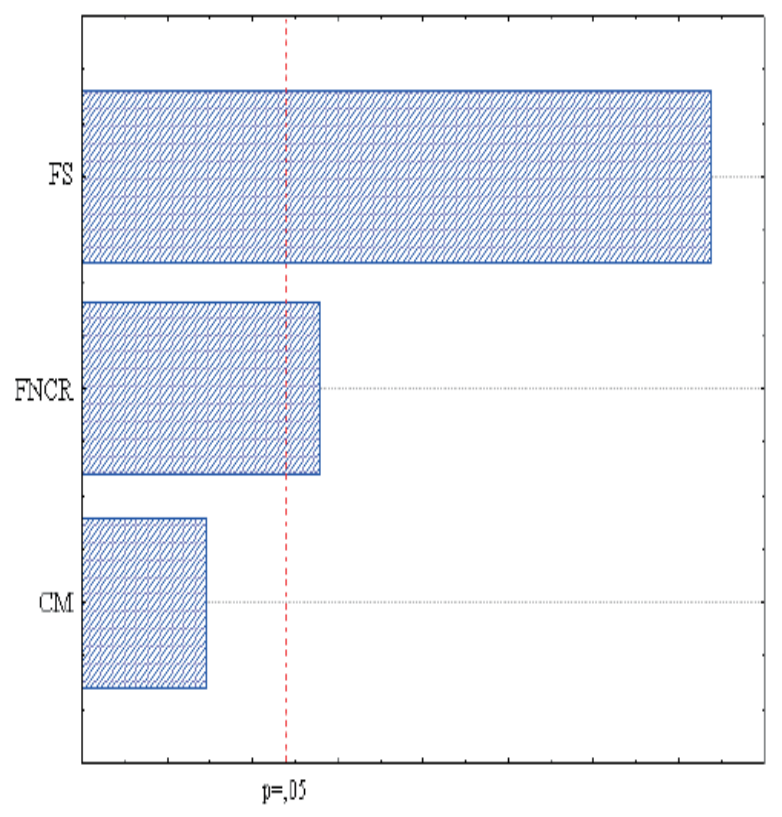

(A)

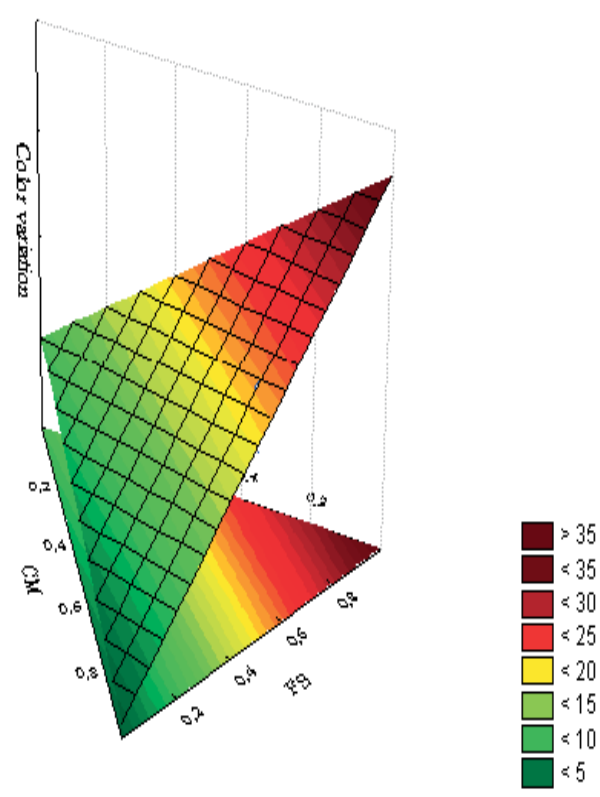

(B)

FIGURE 1. COLOR VARIATION ( $\triangle E$ E) AMONG SEMISWEET BISCUITS MADE WITH CORNMEAL (CM) AND FLOUR OF SHOOTS (FS) AND NON-COMMERCIAL ROOTS (FNCR) OF ARRACACHA 'AMARELA DE CARANDAÍ' (ARRACACIA XANTHORRHIZA BANCROFT). (A) PARETO CHART. (B). RESPONSE SURFACE FOR COLOR VARIATION.

However, in the optimization of biscuit formulation with added flours of arracacha, planning statistical analysis identified there being no significant effect at all quadratic models for parameters of chromaticity, tonality and color variation, as well as in the interaction between meals, with the exception of tonality. However, linear models were statistically significant $(p<0.05)$, with coefficients of determination $\left(R^{2}\right)$ higher than 0.8 and considered satisfactory (Table 5). 
TABLE 5. ANOVA RESULTS FOR MODELS FIT TO DATA ON CHROMATICITY, TONALITY

AND COLOR VARIATION OF SEMISWEET BISCUITS MADE WITH CORNMEAL AND

FLOUR OF SHOOTS AND NON-COMMERCIAL ROOTS OF ARRACACHA 'AMARELA DE CARANDAÍ' (ARRACACIA XANTHORRHIZA BANCROFT)

\begin{tabular}{ccccc}
\hline Variable & Models & $\mathbf{P}^{*}$ & Lack of fit & $\mathbf{R}^{2}$ \\
\hline \multirow{2}{*}{ Cromaticity $\left(\mathbf{C}^{*}\right)$} & Linear & 0.040 & 0.701 & 0.800 \\
\cline { 2 - 5 } & Quadratic & 0.260 & 0.856 & 0.976 \\
\hline \multirow{2}{*}{ Tonality $\left(\mathbf{h}^{*}\right)$} & Linear & 0.001 & 0.951 & 0.968 \\
\cline { 2 - 5 } & Quadratic & 0.028 & 0.998 & 0.999 \\
\hline \multirow{2}{*}{ Color variation $(\Delta \mathrm{E})$} & Linear & 0.003 & 0.913 & 0.942 \\
\cline { 2 - 5 } & Quadratic & 0.230 & 0.888 & 0.981 \\
\hline
\end{tabular}

"Significant level.

For color variation $(\Delta E)$, which involves the $L^{*}, a^{*}$ and $b^{*}$ was generated the significant linear model represented by equation 4 .

$$
Y=2.54 \cdot x_{1}+36 \cdot 20 \cdot x_{2}+10 \cdot 16 \cdot x_{3}
$$

Where $x_{1}, x_{2}$ and $x_{3}$ indicate the proportion of cornmeal, flours of shoots and noncommercial roots that can be inserted in the formulation, respectively, and $Y$ the color variation expected. The graphical representation of Equation 1 can be observed in Figure 1B. This equation indicates that if a formulation was prepared at the point of maximum proportion of $\mathrm{CM}$, the expected color variation result would be 2.54 . If it was prepared at the point of maximum proportion of shoots, it would be 36.16 , and at the point of maximum proportion of non-commercial roots, it would be 10.16. In this study less variation in formulated biscuit color compared with the standard biscuit is expected.

\subsection{PRODUCTION COSTS}

The survey on the cost of a new product is of paramount importance, especially when a conventional ingredient is going to be replaced. One of the goals of substituting cornmeal for flour of non-commercial parts of arracacha is to reduce costs and provide nutritional value equal to or greater than the standard formulation.

The costs to produce $100 \mathrm{~g}$ of biscuits ranged from $\mathrm{R} \$ 1.59$ a 1.73 (Table 6), whereas the higher cost ( $R \$ 1.73)$ was obtained when using $33 \%$ flour of shoots and $33 \%$ flour of noncommercial roots (F7). These data are consistent with those found by GUILHERME and JOKL (2005), who observed higher cost with biscuits prepared with mixed flour; however, these biscuits had better protein quality (Table 3 ). 


\section{TABLE 6. AVERAGE COST (R\$) OF SEMISWEET BISCUITS MADE WITH CORNMEAL (CM) AND FLOURS OF SHOOTS (FS) AND NON-COMMERCIAL ROOTS (FNCR) OF ARRACACHA 'AMARELA DE CARANDAÍ' (ARRACACIA XANTHORRHIZA BANCROFT)}

\begin{tabular}{|c|c|c|c|c|c|c|c|}
\hline \multirow{2}{*}{ Type of Cost } & \multicolumn{7}{|c|}{ Biscuits formulation } \\
\hline & $\mathrm{F} 1$ & $\mathrm{~F} 2$ & F3 & $\mathrm{F} 4$ & F5 & F6 & $\mathrm{F} 7$ \\
\hline Ingredients & 0.46 & 0.44 & 0.46 & 0.45 & 0.45 & 0.46 & 0.47 \\
\hline Operational $^{*}$ & 1.06 & 1.01 & 1.06 & 1.04 & 1.04 & 1.06 & 1.10 \\
\hline Losses $^{* *}$ & 0.15 & 0.14 & 0.15 & 0.15 & 0.15 & 0.15 & 0.16 \\
\hline Total in $\mathrm{R} \$$ & 1.67 & 1.59 & 1.67 & 1.64 & 1.64 & 1.64 & 1.73 \\
\hline
\end{tabular}

*Expenses on human resources, energy, water, packaging and others, beyond the profit margin (133\%)

${ }^{* *}$ Losses occurred during packaging and/or marketing (10\%)

\section{CONCLUSION}

Considering these results, it was concluded that the addition of arracacha residues in the production of biscuit favors the increase of fibers and reduces the calorific value of semisweet biscuits. In addition, biscuits prepared with 100 and $50 \%$ flour of shoots showed darker color compared with other formulations. Biscuits made of flour of non-commercial root were softer in all formulations. Furthermore, biscuits prepared with flour of shoots, despite the higher cost and had better protein quality compared with the standard formulation.

\section{RESUMO}

\section{SUBSTITUIÇÃO DE FUBÁ POR FARINHA DE REBENTOS E RAÍZES NÃO COMERCIAIS DE MANDIOQUINHA-SALSA (ARRACACIA XANTHORRHIZA BANCROFT) NO PROCESSAMENTO DE BISCOITOS SEMIDOCES}

O objetivo foi o desenvolvimento de biscoitos semidoces de fubá com a adição da farinha de rebentos e raízes não comerciais de mandioquinha-salsa (Arracacia xanthorrhiza Bancroft) e a avaliação das implicações nutricionais e das características físicas do produto. As farinhas foram obtidas de amostras frescas de rebentos e raízes não comerciais de mandioquinha-salsa. Os biscoitos foram preparados com diferentes concentrações de fubá, farinha de rebentos e raízes não comerciais de mandioquinha-salsa, totalizando sete formulações. Eles também foram analisados nutricionalmente, tendo o seu custo de produção determinado. A substituição de fubá por farinha de raízes não comerciais até $50 \%$ resultou em biscoitos menos calóricos e com maior conteúdo de fibras. A farinha de rebentos favoreceu o aumento das fibras. No entanto, os biscoitos tiveram coloração mais escura e textura mais dura. Concluiu-se que a adição dos resíduos de mandioquinha-salsa na produção de biscoitos resulta em biscoitos com maior conteúdo de fibras e reduzido valor calórico. 


\section{REFERENCES}

1 AÑES, B.; ESPINOZA, W.; VÁSQUEZ, J. Producción de apio andino en respuesta al su ministro de fertilizantes. Revista Forestal Venezoelana, v.46, p. 39-45, 2002.

2 ASSIS, L.M.; ZAVAREZE, E.R.; RADUNZ, A.L.; DIAS, A.R.G.; GUTKOSKI, L.C.; ELIAS, M.C. Propriedades nutricionais, tecnológicas e sensoriais de biscoitos com substituição de farinha de trigo por farinha de aveia ou farinha de arroz parboilizado. Alimentos e Nutrição, v.20, p. 15-24, 2009.

3 Association of Official Analytical Chemists (2000). Official methods of analysis of AOAC International (AOAC). 12th. ed. Washington, DC.

4 BRASIL. Ministério da Saúde. Agência Nacional de Vigilância Sanitária. RDC n. 12, de 1978. Comissão Nacional de Normas e Padrões de Alimentos - CNNPA / ANVISA - Agência Nacional da Vigilância Sanitária. Normas técnicas especiais São Paulo, São Paulo, 1978. Retrieved from: http://www.anvisa.gov.br legis/resol/12_78. pdf. Accessed in $12 / 05 / 2015$

5 BRASIL. Ministério da Saúde. Agência Nacional de Vigilância Sanitária. RDC n 360, de 23 de dezembro de 2003. Aprova regulamento técnico sobre rotulagem nutricional de alimentos embalados, tornando obrigatória a rotulagem nutricional. Diário oficial da República Federativa do Brasil, Brasília, n. 251, 26 de dezembro de 2003, Seção 1, p. 33. Retrieved from: <http://e-legis.anvisa.gov.br/leisref/public/showAct.php?id=9059>. Accessed in 12/05/2015.

6 CÂMARA, F.L.A.; SANTOS, F.F. Cultura da mandioquinha-salsa. In: CEREDA, M. (ed) Agricultura: tuberosas amiláceas latino americanas. Brazil: Fundação Cargill, 2002, p. 519-532

7 CARVALHO, G.G.; FERNANDES, F.E.P.; AURELIANO, J.V.; PIRES, A.J.V. Métodos de determinação de amido e pectina em alimentos para animais. Revista Electrónica de Veterinaria, v.7, p. 1-12, 2006.

8 EL-DASH, A.; GERMANI, R. Tecnologia de farinhas mistas na produção de biscoitos. Brazil: EMBRAPA, 1994. 47 p.

9 FEDDERN, V.; DURANTE, V.V.O.; MIRANDA, M.Z.; MELLADO, M.L.M.S Avaliação física e sensorial de biscoitos tipo cookie adicionados de farelo de trigo e arroz. Brazilian Journal of Food Technology, v.14, p. 265-272, 2011

10 GRACIANO, J.D.; HEREDIA-ZÁRATE, N.A.; VIEIRA, M.C.; JARDIM-ROSA, Y.B.; SEDIYAMA, M.A.N. Espaçamentos entre fileiras e entre plantas na mandioquinha-salsa 'Branca'. Ciência e Agrotecnologia, v.31, p. 1688-1695, 2007.

11 HEREDIA-ZÁRATE, N.A.; VIEIRA, M.C. Composição nutritiva de rizomas em clones de inhame cultivados em DouradosMS. Pesquisa Agropecuária Tropical, v.34, p. 61-63, 2004.

12 GUILHERME, F.F.P.; JOKL, L. Emprego de fubá de melhor qualidade proteica em farinhas mistas para produção de biscoitos. Ciência e Tecnologia de Alimentos, v.25, p. 63-71, 2005.

13 PAPANTONIOU, E.; HAMMOND, E.W.; TSIAMI, A.A.; SCRIVEN, F.; GORDON, M.H.; SCHOFIELD, J.D. Effects of endogenous flour lipids on the quality of semisweet biscuits. Journal of Agricultural and Food Chemistry, v.51, p. 10571063, 2003.

14 PEREIRA, C.A.; CARLI, L.; BEUX, S.; SANTOS, M.S.; BUSATO, S.B.; KOBELNIK, M.; BARANA, A.C. Utilização de farinha obtida a partir de rejeito de batata na elaboração de biscoitos. Publicatio UEPG: Ciências Exatas e da Terra, Ciências Agrárias e Engenharias, v.11, p. 19-26, 2005.

15 PEREIRA, G.I.S.; PEREIRA, R.G.F.A.; BARCELOS, M.F.P.; MORAIS, A.R. Avaliação química de folha de cenoura visando ao seu aproveitamento na alimentação humana. Ciência e Agrotecnologia, v.27, p. 852-857, 2003.

16 PINTO, N.A.V.D.; CARVALHO, V.D.; BOTELHO, V.A.V.A.; MORAES, A.R. Determinación del potencial de fibras dietéticas en las hojas de taioba (Xanthosoma sagittifolium Schott). Revista Alimentaria, v.5, p. 87-90, 2000.

17 TORALES, E.P.; HEREDIA-ZÁRATE, N.A.; VIEIRA, M.C.; GASSI, R.P.; SALES, N.A.; PINTO, J.V.C. Influência da cama de frango e de espaçamentos entre plantas na produtividade agroeconômica de mandioquinha salsa. Revista Ceres, v.61, p. 162-171, 2014.

18 VIEIRA, M.C.; HEREDIA-ZÁRATE, N.A. Uso de subprodutos de Mandioquinha- Salsa (Arracacia xanthorrhiza), Cará (Dioscorea sp.) e inhame (Colocasia esculenta) na alimentação de frangos de corte. Ciência e Agrotecnologia, v.26, p. 1259-1265, 2002 
19 ZANIN, A.C.W.; CASALI, V.W.D. Origem, distribuição geográfica e botânica da mandioquinha-salsa. Informe Agropecuário, v.10, p. 9-11, 1984.

\section{ACKNOWLEDGMENT}

The authors are grateful to Conselho Nacional de Desenvolvimento Científico e Tecnológico (CNPq), by fellowships and Fundação de Apoio ao Desenvolvimento do Ensino, Ciência e Tecnologia do Estado de Mato Grosso do Sul (FUNDECT/MS), for financial support. 